\title{
Potential Hepatoprotective Activity of Super Critical Carbon Dioxide Olive Leaf Extracts against $\mathrm{CCl}_{4}$-Induced Liver Damage
}

\author{
Amani Taamalli $1,2 \oplus$, Anouar Feriani ${ }^{3}$, Jesús Lozano-Sanchez ${ }^{4,5}, * \mathbb{C}$, Lakhdar Ghazouani $^{3}$, \\ Afoua El Mufti ${ }^{3}$, Mohamed Salah Allagui ${ }^{6}$, Antonio Segura-Carretero ${ }^{4,5}$, Ridha Mhamdi ${ }^{2}$ and \\ David Arráez-Roman 4,5 (D) \\ 1 Department of Chemistry, College of Sciences, University of Hafr Al Batin, P.O. Box 1803, \\ Hafr Al Batin 39524, Saudi Arabia; ataamalli@uhb.edu.sa \\ 2 Laboratoire de Biotechnologie de l'Olivier, Centre de Biotechnologie de Borj-Cedria, B.P.901, \\ Hammam-Lif 2050, Tunisia; ridha.mhamdi@cbbc.rnrt.tn \\ 3 Research Unit of Macromolecular Biochemistry and Genetics, Faculty of Sciences of Gafsa, \\ Gafsa 2112, Tunisia; ferianianwer@yahoo.fr (A.F.); ghazouani2005@yahoo.fr (L.G.); \\ mufti.afoua-90@hotmail.com (A.E.M.) \\ 4 Research and Development Functional Food Centre (CIDAF), Health Science Technological Park, \\ Avenida del Conocimiento 37, Edificio BioRegión, 18016 Granada, Spain; ansegura@ugr.es (A.S.-C.); \\ darraez@ugr.es (D.A.-R.) \\ 5 Department of Analytical Chemistry, Faculty of Sciences, University of Granada, 18071 Granada, Spain \\ 6 Laboratory of Animal Ecophysiology, Faculty of Sciences of Sfax, Sfax 3018, Tunisia; amsallagui@yahoo.fr \\ * Correspondence: jesusls@ugr.es
}

Received: 21 May 2020; Accepted: 16 June 2020; Published: 18 June 2020

check for updates

\begin{abstract}
Virgin olive oil has demonstrated its effective activity against oxidative stress. However, data on the bioactive effect of olive leaves or their major constituents on the liver are scarce. The present research work was conducted to evaluate the hepatoprotective effects of supercritical carbon dioxide $\left(\mathrm{SC}-\mathrm{CO}_{2}\right)$ extracts from fresh and dried olive leaves on hepatotoxicity caused by carbon tetrachloride $\left(\mathrm{CCl}_{4}\right)$ in rat models. For this purpose, healthy albino rats of $180-250 \mathrm{~g}$ weight were used. The assessment of biochemical markers was carried out on blood and liver tissue. Then, a histopathological study was carried out on liver tissue. The obtained results showed that fresh and dried olive leaf extracts ameliorate the perturbed biochemical parameters caused by $\mathrm{CCl}_{4}$ treatment. Furthermore, the results registered for the histopathological study are in accordance with the biochemical parameters and the protective capacity of $\mathrm{SC}-\mathrm{CO}_{2}$ extracts against DNA damage, indicating that olive leaf extracts helped to improve liver fibrosis caused by $\mathrm{CCl}_{4}$ treatment.
\end{abstract}

Keywords: olive leaves; supercritical fluid extraction; antioxidants

\section{Introduction}

Oxidative stress constitutes a disturbance characterized by an imbalance between the generation of free radicals and antioxidant defenses [1]. The reactive oxygen (ROS e.g., O2 ${ }^{-}, \mathrm{OH}, \mathrm{ROO}$ ) and nitrogen species (RNS, e.g., $\mathrm{NO}, \mathrm{ONOO}^{-}$) are generated in a variety of intracellular processes and their overproduction produces cell damage in lipids, proteins and DNA [2].

The liver is the largest organ in the vertebrate body and the site for intense metabolism [3]. It is involved in several vital functions and it has a great capacity to detoxify toxic substances and synthesize useful principles. Therefore damage to the liver inflicted by hepatotoxic substances is of grave consequences [4]. The hepatotoxin $\mathrm{CCl}_{4}$ has been used as a model component causing 
cellular necrosis in the liver. It induces hepatotoxicity in rats, rabbits and humans [5] and mediates its hepatotoxicity after biotransformation by hepatic microsomal cytochrome 450 (CYT 450) to generate trichloromethyl free radicals which launch attacks on membrane proteins, thiols and lipids. This leads to the peroxidation of the lipid membrane which results in necrotic cell death [6]. To prevent such disease, both enzymatic and non-enzymatic mechanisms are present in the cell [7]. The body protects itself from oxygen free radical toxicity by enzymatic antioxidant mechanisms (e.g., glutathione peroxidase, GSH; glutathione reductase, GR; superoxide dismutase, SOD; and catalase, CAT) and by non-enzymatic antioxidants (e.g., vitamins, uric acid, albumin, bilirubin, and many others) [8].

Liver pathologies constitute a serious global health issue despite recent therapeutic advances. Nevertheless, some plants have been used for liver disorders and showed to be therapeutically useful agents [5]. Diverse plant extracts were assessed for their hepatoprotective effect against different experimentally induced liver toxicities [9-15].

From the large diversity of the plant components, special importance has been assigned to their polyphenols, which have shown their capacity to counteract oxidative stress through various mechanisms [16]. An interesting approach used to obtain such compounds is to source them from food industry residues, which are in general disposed of or used to produce animal feed [17]. The olive tree (Olea europaea, L.), amongst the oldest known cultivated trees in the world and mentioned in the Holy Qur'ân and Ahadith [18], has been known for its long history of medicinal and nutritional values. Historically, olive leaves were used as a folk remedy for combating fevers and other diseases, such as malaria. Numerous researchers showed the important role of this plant in improving cardiovascular risk factors [19], cancer [20] and other diseases. A recent publication reviewed the relevant role of phenolic compounds present in Olea europaea, L. products and by-products in human health [21], while another review focused on the potential protective effect of secoiridoids from Olea europaea L. in cancer, cardiovascular, neurodegenerative, aging-related, and immune-inflammatory diseases [20].

Olive leaves constitute a huge abundant residue resulting from olive tree pruning and olive oil processing. It has been estimated that olive pruning produces $25 \mathrm{~kg}$ of olive leaves and twigs per tree annually. In addition these by-products present, only about $10 \%$ of olives actually arrive at the mills [22]. All of this makes olive leaves a very interesting, cheap source with potentially useful bioactive components such as secoiridoids, triterpenes, lignans, and flavonoids [23]. Oleuropein and hydroxytyrosol, as major compounds of olive leaves, have been reported to exert numerous pharmacological properties, including anticancer, antidiabetic, and anti-inflammatory activities [14]. Recently, the hepatoprotective activity of olive leaves against damage induced by $\mathrm{CCl}_{4}$ [24,25], cadmium [26,27], paracetamol [28], thioacetamide [29], ethanol [5], fluoxetine [30] and deltamethrin [31] has receieved increasing interest in animal experiemts. However, available data about the hepatoprotective effect of olive leaf extracts or their major constituents are still scarce. Hence, there is not enough literature about the hepatoprotective effect of olive leaves against $\mathrm{CCl}_{4}$-induced damage. The existing published articles focused on methanolic or butanolic extracts of dried olive leaves obtained by Soxhlet apparatus [24] and ethanolic extract from dried olive leaves standardized to $16-24 \%$ of oleuropein [25]. As far we know, this is the first study on the hepatoprotective effect of Tunisian olive leaves on $\mathrm{CCl}_{4}$-induced toxicity.

Nowadays, supercritical fluid extraction (SFE), an environmentally friendly and selective technique, has become one of the most popular green extraction techniques [32] used mainly in large-scale industrial applications. This technique has several advantages such as high efficacy, rapidity, non-toxicity, the absence of thermal degradation resulting a very high quality extracts, and the possible direct coupling to analytical instrumental technique [33] with a particular green interest due to the use of supercritical fluids such as $\mathrm{CO}_{2}$ instead organic solvents [34]. It has been increasingly used in recent years around the world for the processing of nutraceuticals as a "natural" alternative to traditional solvent-extraction processes [35]. It has acquired some relevance for the extraction of polyphenols from plant sources [36]. No previous literature reported the evaluation of olive leaf supercritical fluid 
extract for its hepatoprotective activity. In our present work, we used fresh and dried leaves from which extracts were obtained using a green advanced extraction technology.

Taking into account all these aspects, this study aimed to assess and compare the hepatoprotective capacity of supercritical carbon dioxide $\left(\mathrm{SC}-\mathrm{CO}_{2}\right)$ extracts of fresh and dried olive leaves in $\mathrm{CCl}_{4}$-induced toxicity in rat models. For this purpose, serum biochemical parameters alanine aminotransferase (ALT), aspartate aminotransferase (AST), alcaline phosphatase (ALP and lactate dehydrogenase (LDH)), liver tissue parameters malondialdehyde (MDA), protein carbonyls (PC), total superoxide dismutase (SOD), catalase (CAT) and glutathione peroxydase (GPX) in addition to histopathological and DNA damage assays were evaluated. As far as we know, this is the first evaluation of the hepatoprotective activity of $\left(\mathrm{SC}-\mathrm{CO}_{2}\right)$ extracts from fresh and dried olive leaves acquired via green technology. Moreover, no available literature evaluated the effect of olive leaf extracts containing phenolic compounds and triterpenoid on induced hepatotoxicity in rats.

\section{Materials and Methods}

\subsection{Plant Material, Supercritical $\mathrm{CO}_{2}$ Extraction and Chemical Characterization}

Olive leaves from the El Hor olive variety cultivated in Kairouan (center of Tunisia) were collected in January 2018 (voucher code OE00182). The cultivar was identified by Pr. Mokhtar Zarrouk. Dried leaves were kept under shade at $25{ }^{\circ} \mathrm{C}$ and fresh leaves were ground using an Ultra Centrifugal Mill ZM 200 (RetschGmbh, Haan, Germany). Extraction of phytochemicals was carried out according to a previously reported method [37]. Briefly, $10 \mathrm{~g}$ of ground leaves were homogenized with sea sand in a ratio 1:1.5 $(\mathrm{m} / \mathrm{m})$, loaded onto the extraction vessel, packed with glass wool and pressurized until working conditions. Extractions were carried out at 150 bar and $40{ }^{\circ} \mathrm{C}$ using a mixture of $\mathrm{CO}_{2}$ and ethanol $(6.6 \%)$ as the extraction solvent which passed through the extraction cell for one hour at $23 \mathrm{~g} / \mathrm{min}$. The obtained extract was finally collected and the solvent was evaporated under vacuum at $38{ }^{\circ} \mathrm{C}$. The extraction yields were $9.3 \%$ and $16.7 \%$ for fresh and dried leaves, respectively.

Olive leaf extracts were analyzed for their phenolic and triterpenoids composition by high performance liquid chromatography coupled to electrospray ionization and time of flight mass spectrometry (HPLC-ESI-TOF/MS). To achieve this goal, SFE extracts were reconstituted in an extraction co-solvent up to a concentration of $5000 \mathrm{mg} / \mathrm{L}$ and filtered through a $0.2 \mu \mathrm{m}$ polytetrafluoroethylene (PTFE) syringe filter prior to further analysis. Qualitative and quantitative determination of both phenolic compounds and terpenoids were carried out according to the previously reported method [38]. Quantitation was carried out using available commercial standards of six phenolics and two terpenoids: hydroxytyrosol, vanillin, luteolin, ferulic acid, (+)-pinoresinol, oleuropein, oleanolic, and maslinic acids. These standards were purchased from Sigma-Aldrich (St. Louis, MO, USA), Arbo Nova (Turku, Finland), and Extrasynthèse (Lyon, France). The stock solutions containing these analytes were prepared by dissolving the appropriate amount in methanol or methanol/water $(50 / 50, v / v)$ at a concentration level of $1 \mathrm{mg} / \mathrm{L}$. All calibration curves showed good linearity over the range of study with a minimum value of $R^{2}=0.994$.

\subsection{Experimental Animals and Toxicity Test}

Healthy adult male albino rats weighing 180-250 g were used. The animals were provided from Pasteur institute and housed in a plastic cage under controlled temperature $\left(24 \pm 2{ }^{\circ} \mathrm{C}\right), 12 \mathrm{~h} \mathrm{light} / \mathrm{dark}$ cycle and $55 \pm 5 \%$ relative humidity. The animals were guarded in the laboratory (Faculty of Sciences, Gafsa, Tunisia) for seven days before experiences with free access to standard laboratory food (SNA -Sfax) and water ad libitum. Animals were treated in accordance with guidelines and according to the Medical Ethics Committee for the Care and Use of Laboratory Animals of the Pasteur Institute of Tunis, Tunisia (approval number: FST/LNFP/Pro 152012).

The toxicity of SC- $\mathrm{CO}_{2}$ extracts of fresh leaves and dried leaves mixed with corn oil was tested by gavage administration of four doses at $5,10,20$ and $30 \mathrm{mg} / \mathrm{kg}$ body weight (b.w.). Animals ( $n=6$ in 
each group) were carefully controlled for progress of any toxicological symptoms at $30 \mathrm{~min}$ and then 4 , 12,24 and $48 \mathrm{~h}$.

\subsection{Animals and Experimental Design of the $\mathrm{CCl}_{4}$-Induced Hepatotoxicity}

To test the potential hepatoprotective effects of olive leaf extracts, experiments were conducted in six groups according to the following administration (Scheme 1): group I-negative control with administration of vehicle only (corn oil); group II—administration of carbon tetrachloride $\left(\mathrm{CCl}_{4}\right)$ in corn oil $50 \mu \mathrm{L} / \mathrm{kg}$ [39]; group III—daily administration of fresh leaf extracts dissolved in corn oil (FLE, $30 \mathrm{mg} / \mathrm{kg}$ ); group IV—-daily administration of dried leaf extracts dissolved in corn oil (DLE, $30 \mathrm{mg} / \mathrm{kg}$ ); group V-administration of FLE $(30 \mathrm{mg} / \mathrm{kg})$ and simultaneous treatment with $\mathrm{CCl}_{4}(50 \mu \mathrm{L} / \mathrm{kg})+$; group VI—administration of DLE (30 mg/kg) and simultaneous treatment with $\mathrm{CCl}_{4}(50 \mu \mathrm{L} / \mathrm{kg})$.

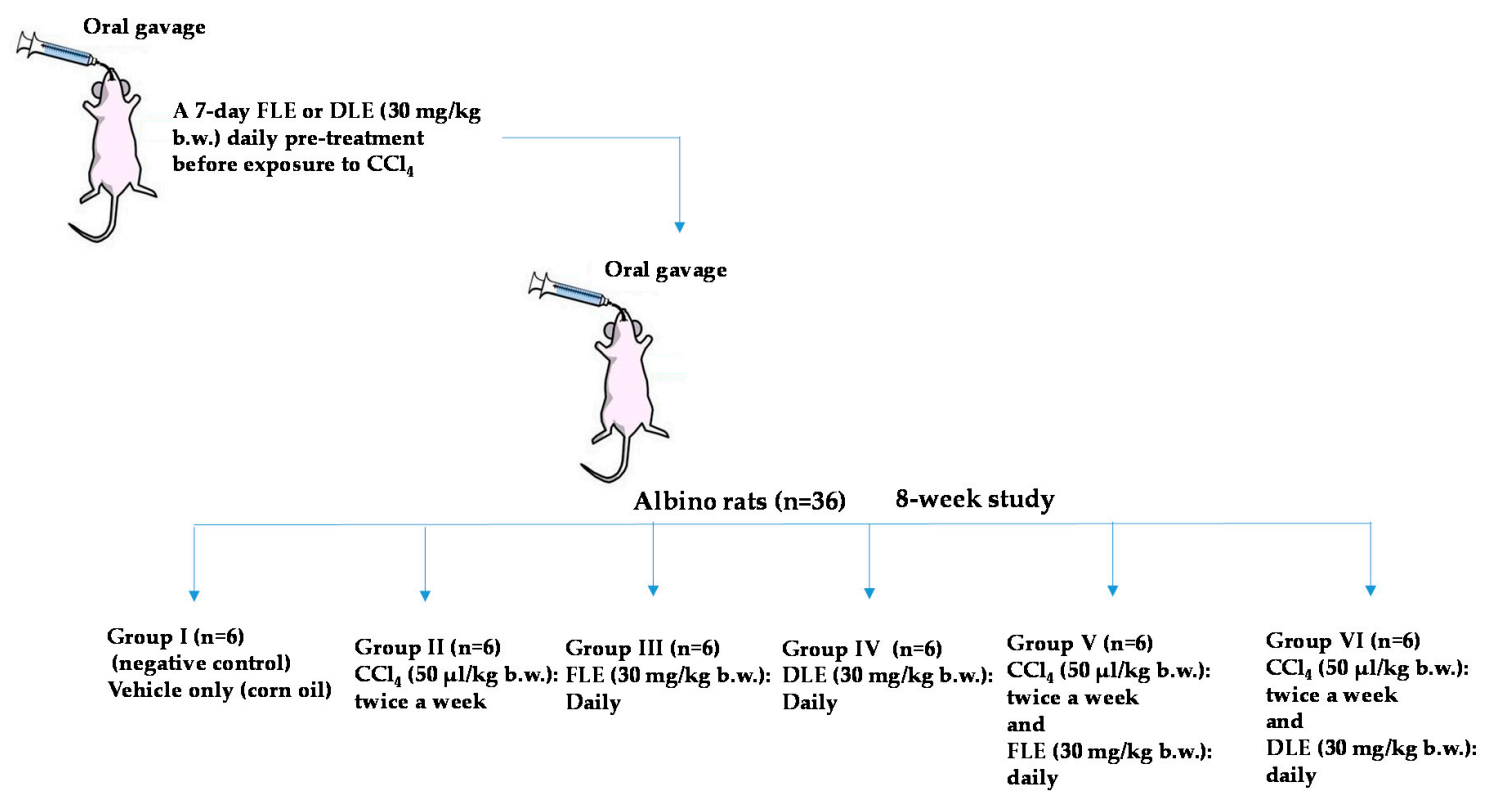

Scheme 1. Graphical scheme summarizing the experimental design, $n$ : number of rats.

The $\mathrm{CCl}_{4}$ was administered by gastric gavage twice per week (on every Tuesday and Thursday) over eight weeks. A daily pretreatment with FLE or DLE was realized 7 days before $\mathrm{CCl}_{4}$ exposure and then daily throughout the research work by gastric gavage. The rats were sacrificed at the end of eight weeks and $24 \mathrm{~h}$ after the last dose of the hepatotoxin.

\subsection{Analysis of Liver-Damage Serum Markers}

Blood samples were obtained by cardiac puncture. After coagulation, the samples were centrifuged at $3000 \times \mathrm{g}$ for $10 \mathrm{~min}$ and serum was stored at $-20{ }^{\circ} \mathrm{C}$ for further analysis. Levels of alanine aminotransferase, aspartate aminotransferase, alcaline phosphatase and lactate dehydrogenase were determined by spectrophotometric assays according to the commercially available diagnostic kits (Biomaghreb, Ariana, Tunisia).

\subsection{Biological Determination of Liver Tissue}

\subsubsection{Preparation of Tissue Extracts}

The liver tissues were homogenized into $2 \mathrm{~mL}$ of ice-cold lyses buffer $(\mathrm{pH}=7.4)$ using a grinder (homogenizer ultra-turrax). Then, the homogenate was centrifuged $\left(12,000 \mathrm{rpm}, 4{ }^{\circ} \mathrm{C}\right)$ for $15 \mathrm{~min}$. The obtained supernatant was frozen at $-20^{\circ} \mathrm{C}$ to determine the oxidative stress biomarkers: malondialdehyde (MDA), protein carbonyls (PC), SOD, CAT and GPX. 


\subsubsection{Measurement of Lipid Peroxidation and Protein Oxidation in Hepatic Tissue}

The lipid peroxidation was estimated in control and treated rats by the quantification of thiobarbituric acid-reactive substances (TBARS) using the method described previously [24]. Briefly, the solution containing $100 \mu \mathrm{L}$ of liver tissue extract and $100 \mu \mathrm{L}$ of trichloroacetic acid (TCA, 5\%) was centrifuged at $4000 \times g$ for $10 \mathrm{~min}$. Then, in a boiling water bath, $100 \mu \mathrm{L}$ of the supernatant was incubated with $200 \mu \mathrm{L}$ of thiobarbituric acid reagent (TBA, $0.67 \%$ ) for $15 \mathrm{~min}$. The absorbance was read at $530 \mathrm{~nm}$, the degree of lipid peroxidation was measured as thiobarbituric acid reactive substances (TBARS) and the result was expressed as nmol of MDA equivalents per gram of tissue (nmol MDA equivalents/g tissue).

The protein carbonyl (PC) level was determined using the method described in the literature [40]. In this method, the carbonyl group of proteins was measured in the resulting pellets by reaction with 2,4-dinitrophenylhydrazine to form protein hydrazone which was measured spectrophotometrically at $370 \mathrm{~nm}$.

\subsubsection{Determination of Enzymatic Antioxidants Activities}

Total SOD activity, expressed as units per milligram of protein, was determined by measuring the inhibition of pyrogallol activity [41]. One unit (U) corresponded to the enzyme activity necessary to inhibit the oxidation of half of the pyrogallol.

Catalase activity was determined in tissue supernatants using hydrogen peroxide $\left(\mathrm{H}_{2} \mathrm{O}_{2}\right)$ as substrate according to the literature [42]. $\mathrm{H}_{2} \mathrm{O}_{2}$ degradation was accompanied by a decrease in absorbance and it was confirmed by measuring the absorbance at $240 \mathrm{~nm}$ for $1 \mathrm{~min}$, and the enzyme activity was expressed as $m m o l \mathrm{H}_{2} \mathrm{O}_{2}$ consumed per minute per milligram of protein.

Glutathione peroxidase activity was assayed by the subsequent oxidation of NADPH at $340 \mathrm{~nm}$, using the method described by Flohé and Günzler [43], and the results were expressed as nmol of GSH oxidized per minute per milligram of protein.

Finally, protein concentration in liver homogenates was measured by the Bradford technique ((BCA) Protein Assay Kit, Pierce Biotechnology Inc., Rockford, USA) with bovine serum albumin (BSA) as standard.

\subsection{Histopathological Study}

The liver samples of the rats were fixed in $10 \%$ buffered formalin. After fixation, the tissues were dehydrated in a graded series of alcohol, cleared in xylene, embedded in paraffin, and cut into $5 \mu \mathrm{m}$ thick slices. These serial tissue sections were stained with hematoxylin and eosin (HE) for routine histological examination. Sirius Red and Masson's trichrome staining were used to visualize the collagen deposit in hepatic tissue, which was coloured blue using Masson's trichrome and red by Sirius Red staining. The specimens were observed and photographed through a light microscope (Olympus CX31, Hamburg, Germany).

\subsection{DNA Fragmentation Assay}

Genomic DNA in the liver tissue of control and treated rats was isolated by phenol-chloroform DNA extraction method. The separation of intact and fragmented DNA fractions was visualized in an agarose gel by ethidium bromide staining, following the protocol described in the literature [44].

\subsection{Statistical Analysis}

Statistical analysis was performed using GraphPad Prism 4.02 (GraphPad Software, San Diego, CA, USA). One-way analysis of variance (ANOVA) together with Tukey test were applied to observe significant differences between the tested treatments at a significance level $(p<0.05)$. 


\section{Results}

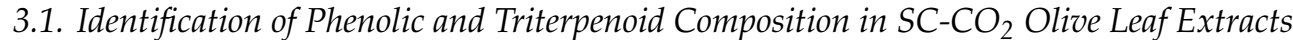

In Table 1 are summarized the different compounds detected in both FLE and DLE. The analysis of the extract composition permitted the chemical characterization of 16 compounds. Quantitative results showed in this table include the amount of each identified compound in the administered dose to evaluate the hepatoprotective effects.

Table 1. Identified and quantified phytochemicals in the $\mathrm{SC}-\mathrm{CO}_{2}$ olive leaf extracts.

\begin{tabular}{cccccc}
\hline $\begin{array}{c}m / z \\
{[\mathbf{M}-\mathbf{H}]^{-}}\end{array}$ & $\begin{array}{c}\text { Molecular } \\
\text { Formula }\end{array}$ & Compound & FLE & DLE & Classification \\
\hline 389.1089 & $\mathrm{C}_{16} \mathrm{H}_{22} \mathrm{O}_{11}$ & Secologanoside & - & $0.15 \pm 0.2$ & Phenolic compound \\
153.0557 & $\mathrm{C}_{8} \mathrm{H}_{10} \mathrm{O}_{3}$ & $\begin{array}{c}\text { Hydroxytyrosol } \\
\text { Elenolic acid glucoside }\end{array}$ & - & $19 \pm 1$ & Phenolic compound \\
403.1246 & $\mathrm{C}_{17} \mathrm{H}_{24} \mathrm{O}_{11}$ & isomer 1 & $0.05 \pm 0.01$ & Phenolic compound \\
151.0401 & $\mathrm{C}_{8} \mathrm{H}_{8} \mathrm{O}_{3}$ & Vanillin & $3 \pm 0.3$ & $13.0 \pm 0.4$ & Phenolic compound \\
403.1246 & $\mathrm{C}_{17} \mathrm{H}_{24} \mathrm{O}_{11}$ & Elenolic acid glucoside & - & $0.70 \pm 0.01$ & Phenolic compound \\
193.0506 & $\mathrm{C}_{10} \mathrm{H}_{10} \mathrm{O}_{4}$ & isomer 2 & - & $0.40 \pm 0.01$ & Phenolic compound \\
539.177 & $\mathrm{C}_{25} \mathrm{H}_{32} \mathrm{O}_{13}$ & Oleuropein isomer 1 & - & $42 \pm 1$ & Phenolic compound \\
539.177 & $\mathrm{C}_{25} \mathrm{H}_{32} \mathrm{O}_{13}$ & Oleuropein isomer 2 & - & $1.10 \pm 0.01$ & Phenolic compound \\
417.1555 & $\mathrm{C}_{22} \mathrm{H}_{26} \mathrm{O}_{8}$ & Syringaresinol & $2.4 \pm 0.1$ & & Phenolic compound \\
357.1344 & $\mathrm{C}_{20} \mathrm{H}_{22} \mathrm{O}_{6}$ & Pinoresinol & $1.1 \pm 0.3$ & $0.8 \pm 0.2$ & Phenolic compound \\
415.1398 & $\mathrm{C}_{22} \mathrm{H}_{24} \mathrm{O}_{8}$ & Acetoxypinoresinol & $37 \pm 1$ & $1 \pm 0.1$ & Phenolic compound \\
299.0561 & $\mathrm{C}_{16} \mathrm{H}_{12} \mathrm{O}_{6}$ & Diosmetin & $2 \pm 0.2$ & $0.040 \pm 0.002$ & Phenolic compound \\
471.348 & $\mathrm{C}_{30} \mathrm{H}_{48} \mathrm{O}_{4}$ & Maslinic acid & $935 \pm 7$ & - & Triterpenoid \\
455.3531 & $\mathrm{C}_{30} \mathrm{H}_{48} \mathrm{O}_{3}$ & Oleanolic acid & $1902 \pm 8$ & $867 \pm 6$ & Triterpenoid \\
455.3531 & $\mathrm{C}_{30} \mathrm{H}_{48} \mathrm{O}_{3}$ & Ursolic acid & $1539 \pm 11$ & $1479 \pm 7$ & Triterpenoid \\
401.1453 & $\mathrm{C}_{18} \mathrm{H}_{26} \mathrm{O}_{10}$ & Benzyl alcohol pentose & - & $0.05 \pm 0.00$ & Other polar compound \\
\hline
\end{tabular}

Value $=\mathrm{X} \pm \mathrm{SD}$ ( $\mu \mathrm{g}$ of compound per $30 \mathrm{mg}$ of extract), not detected (-).

A clear qualitative and quantitative difference was observed between fresh and dried leaves. In fresh leaves only vanillin, lignans (pinoresinol and acetoxypinoresinol), diosmetin and triterpenoids (maslinic, ursolic and oleanolic acids) were detected. This could be related to the impact of drying on the quality and the composition of olive leaf extract. Regarding the administered dose, acetoxypinoresinol was the major phenolic compound and constituted $37 \mu \mathrm{g}$ in FLE, whereas in DLE, oleuropein formed the major phenolic compound $(42 \mu \mathrm{g})$ followed by hydroxytyrosol (19 $\mu \mathrm{g})$. Regarding triterpenoids, ursolic acid was the major compound in both extracts, being higher in fresh olive leaf extract.

\subsection{Biochemical Measurements}

\subsubsection{Effect on Plasma Biochemical Markers}

Table 2 summarizes the impact of the hepatotoxin and olive leaf extract administration on liver function tests. Compared to the control group, the ALT, AST, ALP and LDH activities in serum of rats treated with $\mathrm{CCl}_{4}$ increased significantly $(p<0.001)$ after eight weeks reaching 336, 417, 231 and $261 \mathrm{U} / \mathrm{L}$, respectively, indicating acute hepatocellular damage (Table 2). Nevertheless, the oral administration of olive leaf extracts (dose of $30 \mathrm{mg} / \mathrm{kg}$ b.w.) during intoxication showed a significant decrease in AST, ALT, ALP and LDH activities compared to $\mathrm{CCl}_{4}$ only-treated rats. 
Table 2. Effect of $\mathrm{CCl}_{4}, \mathrm{FLE}$ and DLE administration on hepatic biochemical markers.

\begin{tabular}{ccccc}
\hline & AST (U/L) & ALT (U/L) & ALP (U/L) & LDH (U/L) \\
\hline Control & $355 \pm 8$ & $285 \pm 4$ & $161 \pm 5$ & $205 \pm 5$ \\
CCl $_{4}$ & $417 \pm 4^{* * *}$ & $336 \pm 9^{* * *}$ & $231.9 \pm 0.8^{* * *}$ & $261 \pm 5^{* * *}$ \\
FLE & $371 \pm 4$ & $276 \pm 2$ & $171 \pm 4$ & $199 \pm 8$ \\
$\mathrm{CCl}_{4}+$ FLE & $402 \pm 3^{+}$ & $308 \pm 9^{++}$ & $207 \pm 2^{++}$ & $240 \pm 5^{++}$ \\
DLE & $354 \pm 5$ & $281 \pm 6$ & $158 \pm 9$ & $207 \pm 7$ \\
$\mathrm{CCl}_{4}+$ DLE & $389 \pm 4^{+++}$ & $316 \pm 3^{+}$ & $211 \pm 3^{+}$ & $242 \pm 4^{+}$ \\
\hline
\end{tabular}

AST: aspartate aminotransferase; ALT: alanine aminotransferase; ALP: alkaline, phosphatase and LDH: lactate dehydrogenase. Values are expressed as mean $\pm \mathrm{SD}$ of six rats in each group. $\mathrm{CCl}_{4}$ group versus control group: ${ }^{* *} p<0.01 ;{ }^{* * *} p<0.001 . \mathrm{CCl}_{4}+\mathrm{FLE}$ or $\mathrm{CCl}_{4}+$ DLE group versus $\mathrm{CCl}_{4}$ group: ${ }^{+} p<0.05{ }^{++} p<0.01 ;{ }^{+++} p<0.001$.

The observed decrease was more pronounced in terms of AST activity when DLE was administered (389 U/L, $p<0.001$ ) during $\mathrm{CCl}_{4}$ toxicity. Contrastingly, FLE administration in intoxicated rats caused a slightly more important decrease than with DLE administration in terms of ALT, ALP and LDH activities (Table 1).

\subsubsection{Lipid Peroxidation and Protein Carbonyls}

The effect on lipid peroxidation and protein carbonyls contents are summarized in Table 3. For $\mathrm{CCl}_{4}$-intoxicated rats, the TBARS level increased significantly (4.6 nmol MDA equivalents/g tissue) when compared with the control group (1.13 nmol MDA equivalents/g of tissue). Nevertheless, treatment with olive leaf extracts significantly reduced the lipid peroxidation level in $\mathrm{CCl}_{4}$-treated rats to $2.9 \mathrm{nmol} \mathrm{MDA}$ equivalents/g tissue in the case of $\mathrm{FLE}+\mathrm{CCl}_{4}$ and $2.7 \mathrm{nmol} \mathrm{MDA}$ equivalents/g of tissue in the case of DLE $+\mathrm{CCl}_{4}$.

Likewise, protein carbonyl amounts significantly increased $(* * * * 0.001)$ further $\mathrm{CCl}_{4}$ intoxication ( $2.7 \mathrm{nmol} / \mathrm{mg}$ protein) in comparison to the control group ( $1 \mathrm{nmol} / \mathrm{mg}$ protein). However, FLE pretreatment of intoxicated rats showed a more pronounced effect than DLE pretreatment when compared to intoxicated rats $(1.6 \mathrm{nmol} / \mathrm{mg}$ protein) with values of $1.0,2.7$ and $2.03 \mathrm{nmol} / \mathrm{mg}$ protein for control, $\mathrm{CCl}_{4}$ and DLE $+\mathrm{CCl}_{4}$ treatment, respectively.

A significant increase $\left.{ }^{* *} p<0.01\right)$ was registered in terms of SOD, CAT and GPx activities among those in the $\mathrm{CCl}_{4}$-treated group $\left(141 \mathrm{U} / \mathrm{mg}\right.$ protein, $136 \mu \mathrm{mol}$ of $\mathrm{H}_{2} \mathrm{O}_{2}$ destroyed/min per $\mathrm{mg}$ protein and $100 \mathrm{nmol}$ of NADPH oxidized/min per mg protein, respectively) when compared to the control group $\left(89 \mathrm{U} / \mathrm{mg}\right.$ protein, $109 \mu \mathrm{mol}$ of $\mathrm{H}_{2} \mathrm{O}_{2}$ destroyed/min per mg protein and $83 \mathrm{nmol}$ of NADPH oxidized/min per mg protein, respectively). In contrast, SOD, CAT and GPx activities significantly decreased $(p<0.05)$ in intoxicated rats pretreated with DLE or FLE when compared to the rats who received only $\mathrm{CCl}_{4}$ (Table 3). 
Table 3. Effect of $\mathrm{CCl}_{4}$, FLE and DLE on liver oxidative stress.

\begin{tabular}{|c|c|c|c|c|c|}
\hline & $\begin{array}{c}\text { TBARS (nmol MDA } \\
\text { Equivalents/g Tissue) }\end{array}$ & PC (nmol/mg Protein) & SOD (U/mg Protein) & $\begin{array}{c}\text { CAT }\left(\mu \mathrm{mol} \text { of } \mathrm{H}_{2} \mathrm{O}_{2}\right. \\
\text { Destroyed } / \mathrm{min} \\
\text { per mg Protein) }\end{array}$ & $\begin{array}{c}\text { GPx (nmol of NADPH } \\
\text { Oxidized/min } \\
\text { per mg Protein) }\end{array}$ \\
\hline Control & $1.13 \pm 0.2$ & $1.0 \pm 0.1$ & $89 \pm 3$ & $109 \pm 8$ & $83 \pm 3$ \\
\hline $\mathrm{CCl}_{4}$ & $4.6 \pm 0.3^{* * *}$ & $2.7 \pm 0.3^{* * *}$ & $141 \pm 9^{* * *}$ & $136 \pm 6^{* *}$ & $100 \pm 4^{* *}$ \\
\hline FLE & $1.4 \pm 0.4$ & $0.9 \pm 0.2$ & $78 \pm 4$ & $98 \pm 4$ & $73 \pm 4$ \\
\hline $\mathrm{CCl}_{4}+\mathrm{FLE}$ & $2.9 \pm 0.7^{+}$ & $1.6 \pm 0.1^{+++}$ & $125 \pm 3^{+}$ & $119 \pm 4^{+}$ & $81 \pm 1^{++}$ \\
\hline DLE & $1.0 \pm 0.7$ & $1.1 \pm 0.2$ & $87 \pm 2$ & $98 \pm 9$ & $74 \pm 7$ \\
\hline $\mathrm{CCl}_{4}+\mathrm{DLE}$ & $2.7 \pm 0.4^{++}$ & $2.03 \pm 0.05^{++}$ & $123 \pm 5^{++}$ & $120 \pm 1^{+}$ & $87 \pm 5^{+}$ \\
\hline
\end{tabular}




\subsubsection{Evaluation of Enzymatic Antioxidant Activities}

Table 3 also shows the effects of olive leaf extracts on the antioxidant enzymes. It is noteworthy to say that $\mathrm{CCl}_{4}$ caused a significant increase in SOD, CAT and GPx activities (141 U/mg protein, $136 \mu \mathrm{mol}$ of $\mathrm{H}_{2} \mathrm{O}_{2}$ destroyed/min per mg protein and $100 \mathrm{nmol}$ of NADPH oxidized/min per mg protein, for SOD, CAT and GPx, respectively) when compared to the control group ( $89 \mathrm{U} / \mathrm{mg}$ protein, $109 \mathrm{U} / \mathrm{mg}$ protein and $83 \mathrm{U} / \mathrm{mg}$ protein, for SOD, CAT and GPx, respectively). Contrastingly, olive leaf extract administration caused a significant decrease in the activity of such enzymes when compared to $\mathrm{CCl}_{4}$-treated animals, resulting in levels close to those of the control group, especially for GPx activity (81 and $87 \mathrm{nmol}$ of NADPH oxidized/min per mg protein, respectively, in comparison to the control rats with $83 \mathrm{nmol}$ of NADPH oxidized/min per $\mathrm{mg}$ protein).

\subsection{Histopathological Examinations}

\subsubsection{Hematoxylin and Eosin (HE) Staining}

(HE) staining of hepatic tissues of control and all treated rats are demonstrated in Figure 1. As it can be observed, the figure shows the hepatoprotective effect of FLE and DLE after $\mathrm{CCl}_{4}$ hepatotoxin administration.

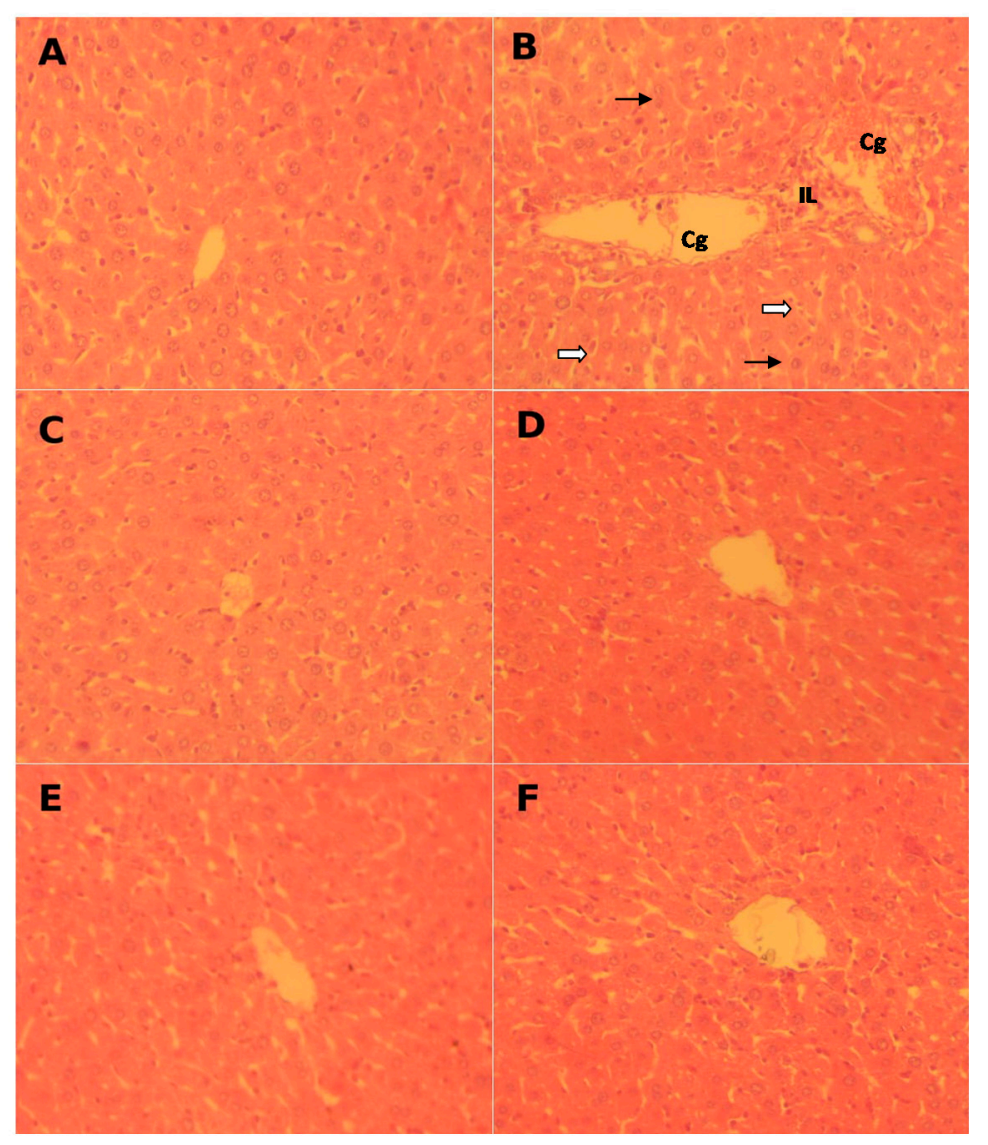

Figure 1. Pathological histology analysis in rat liver tissues after HE staining (magnification: 200X): (A) controls, (B) $\mathrm{CCl}_{4}$-treated $\left(\mathrm{CCl}_{4}\right)$; (C) FLE-treated (FLE), and (D) $\mathrm{CCl}_{4}$-treated co-treated with FLE $\left(\mathrm{CCl}_{4}+\mathrm{FLE}\right)$. (E) DLE-treated (DLE), and (F) $\mathrm{CCl}_{4}$-treated cotreated with DLE $\left(\mathrm{CCl}_{4}+\mathrm{DLE}\right)$. Each microphotograph shows a section of an individual liver. Extensive focal necrosis $(\vec{\square})$, a moderate Kupffer cell hyperplasia $(\longrightarrow)$, congestion and dilatation of the central vein $(\mathrm{Cg})$ and leukocyte infiltration (LI). 
The control rats' hepatic sections revealed a normal form of hepatic cells; polyhedral hepatocytes and sinusoids boundaries exhibited a single layer of fenestrated endothelial and Kupffer cells (Figure 1A). FLE and DLE alone had no significant effects on liver histology (Figure 1C,E) whilst hepatoxin administration resulted in cells injury (Figure 1B). This was marked by extensive focal necrosis, a moderate Kupffer cell hyperplasia, congestion and dilatation of the central vein, and leukocyte infiltration. Finally, following the administration of $\mathrm{CCl}_{4}+\mathrm{FLE}$ or $\mathrm{CCl}_{4}+\mathrm{DLE}$, focal neutrophils were infiltrated in some space and a number of centrilobular veins were congested (Figure 1D,F).

\subsubsection{Sirius Red and Masson's Trichrome Staining}

Sirius Red and Masson's trichrome staining of hepatic cells are shown in Figures 2 and 3.

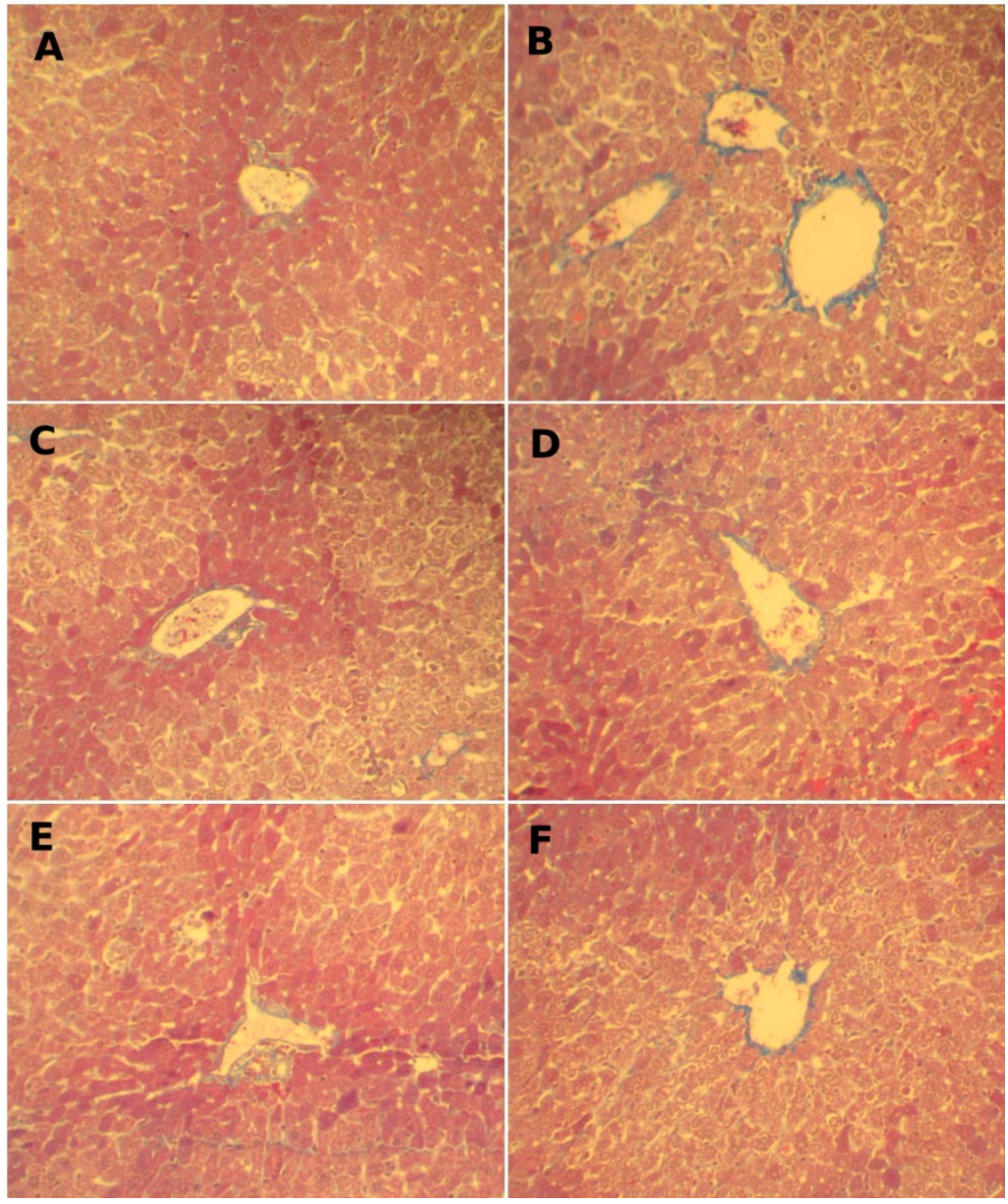

Figure 2. Effect of FLE and DLE on hepatic connective tissue fibrosis caused by $\mathrm{CCl}_{4}$ treatment: assessment by Masson's trichrome stain $(\mathrm{G} \times 200)$. (A) Control, (B) $\mathrm{CCl}_{4}$-treated, blue-stained zone indicates increasing fibrosis. (C) FLE-treated (30 mg/kg), and (D) co-treated with $\mathrm{CCl}_{4}$ and FLE $(30 \mathrm{mg} / \mathrm{kg})$; (E) DLE-treated (30 mg/kg) showing normal structure and (F) co-treated with $\mathrm{CCl}_{4}$ and DLE $(30 \mathrm{mg} / \mathrm{kg})$ showing results close to the control.

Microscopic observations of the hepatic tissues of control group (Figure 2A) and those of groups pretreated with FLE and DLE (Figures 2 and 3C,E) show a normal distribution of collagen fibers between the portal spaces and the centrilobular vein manifested by a low red and blue color. After treatment with $\mathrm{CCl}_{4}$ (Figures 2 and 3B), fibrous collagen bridges (shown by the intense red and blue stains) were formed between portal spaces and the centrilobular, marking hepatic fibrosis. 


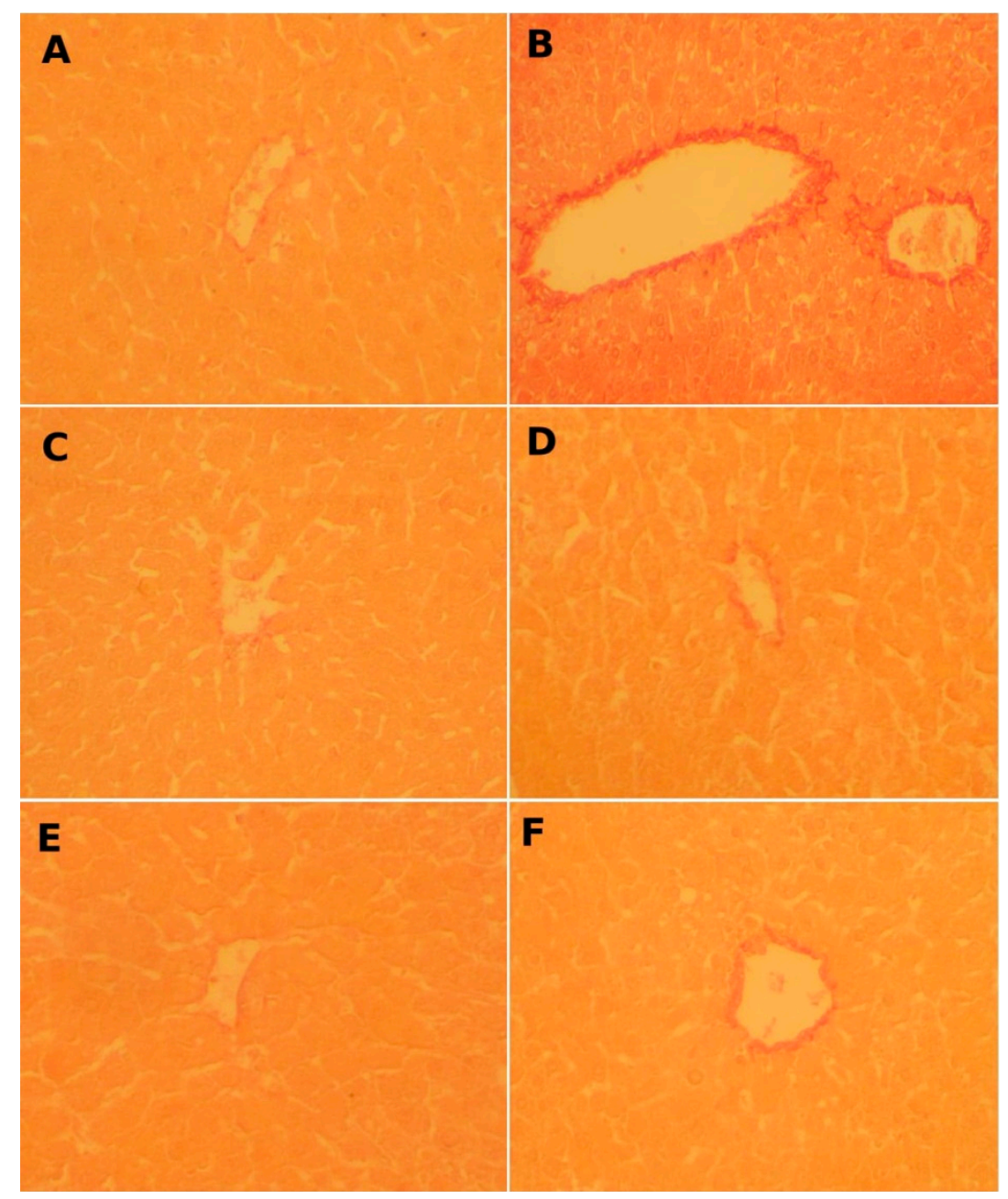

Figure 3. Micrograph showing the effect of FLE and DLE on hepatic fibrosis caused by $\mathrm{CCl}_{4}$. Assessment by Sirius red stain $(\mathrm{G} \times 200)$. (A) Control, (B) $\mathrm{CCl}_{4}$-treated, showing intensified red stain. (C) FLE-treated $(30 \mathrm{mg} / \mathrm{kg})$, and (D) co-treated with $\mathrm{CCl}_{4}$ and FLE $(30 \mathrm{mg} / \mathrm{kg})$. (E) DLE-treated $(30 \mathrm{mg} / \mathrm{kg})$ showing normal collagen deposition and (F) co-treated with $\mathrm{CCl}_{4}$ and DLE $(30 \mathrm{mg} / \mathrm{kg})$.

Concerning the association with FLE and DLE, the study revealed that these extracts exerted a protective effect against $\mathrm{CCl}_{4}$-induced hepatic fibrotic scarring, observed through the decreasing red and blue staining when compared to that of control (Figures 2 and 3D,F).

\subsection{Effects of Olive Leaf Extracts on the DNA Fragmentation}

As shown in Figure 4, the DNA extracted from the hepatic sections has changed qualitatively. The control group DNA (lane 1) and that of FLE or DLE-treated groups (lanes 3 and 4) showed an intact band. However, we observed that DNA degraded after treatment with the $\mathrm{CCl}_{4}$ (lane 2 and lane 6), marked by an obvious smearing and laddering which indicates apoptosis. In the FLE $+\mathrm{CCl}_{4}$ and $\mathrm{DLE}+\mathrm{CCl}_{4}$ rats (lane 5 and lane 7), the olive leaf extract addition shows its effect on preventing DNA damage and provides results close to those of the control rats, as observed in Figure 4. 


$\begin{array}{lllllll}\text { Control } & \mathrm{CCl}_{4} & \mathrm{FLE} & \mathrm{DLE} & \mathrm{FLE}+\mathrm{CCl}_{4} & \mathrm{CCl}_{4} & \mathrm{DLE}+\mathrm{CCl}_{4}\end{array}$

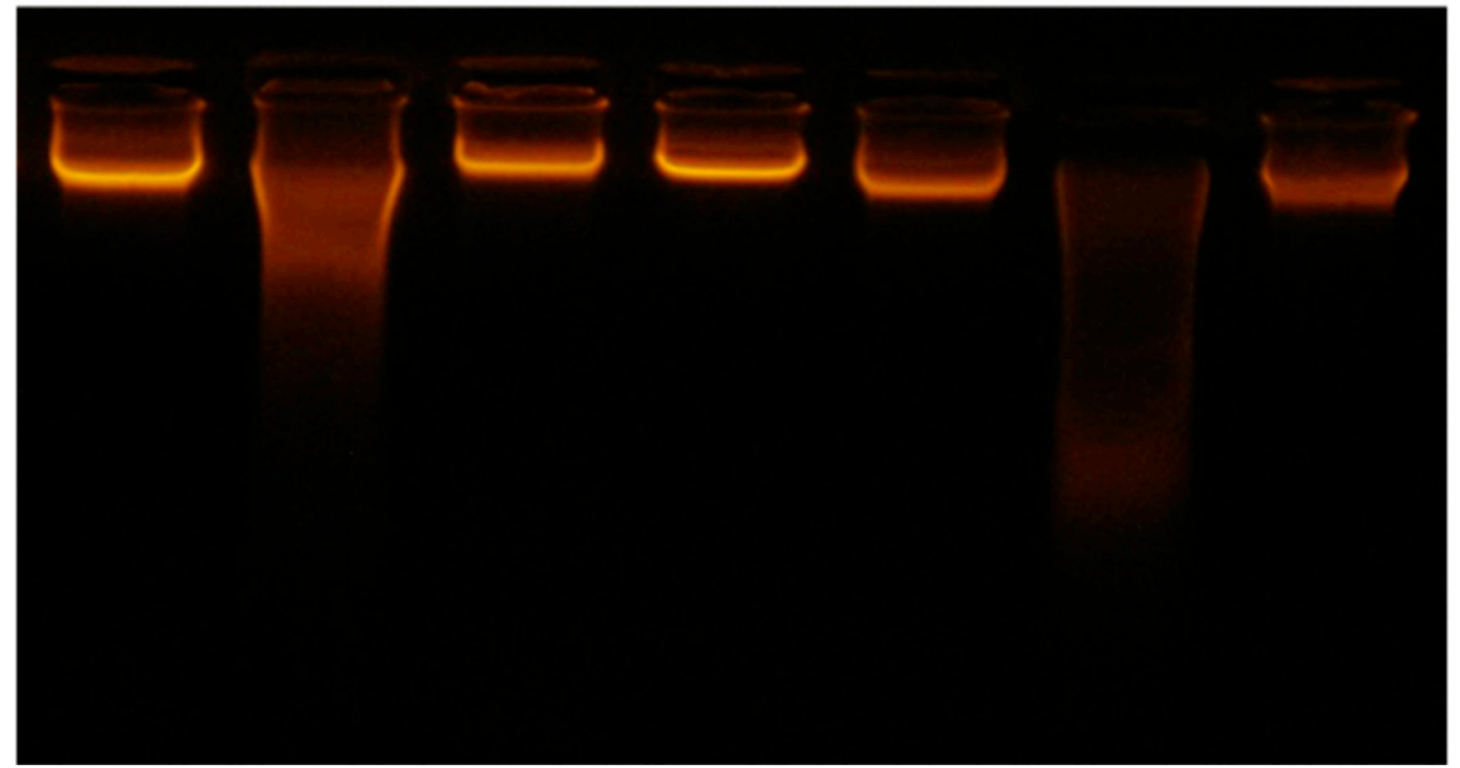

Figure 4. Agarose gel electrophoresis of DNA fragmentation. Lane 1: control hepatic tissue DNA; lane 2 and lane 6: $\mathrm{CCl}_{4}$ intoxicated liver DNA, lane 3 and lane 4: FLE- or DLE-treated liver DNA; lane 5 and lane 7: $\mathrm{FLE}+\mathrm{CCl}_{4}$ - or DLE $+\mathrm{CCl}_{4}$ - treated liver DNA.

\section{Discussion}

Despite recent therapeutic advances, many liver diseases remain relentlessly progressive because specific therapies to target the underlying etiologies of the liver diseases are not available. Therefore, the demand for liver transplantation is likely to increase unless more effective therapeutic and anti-fibrotic agents are developed [45].

In this research work, healthy adult male albino rats were used as an experimental model for the evaluation of olive leaf extracts on induced hepatotoxicity. Among the known hepatotoxic agents, $\mathrm{CCl}_{4}$ is the best model of oxidative stress-induced liver damage and is commonly used to assay the hepatoprotective capacity of drugs [46].

The obtained results revealed that the oral gavage of $\mathrm{SC}-\mathrm{CO}_{2}$ olive leaf extracts effectively attenuated the $\mathrm{CCl}_{4}$-induced hepatic damage and fibrotic scarring in rats. The hepatotoxin-caused injury was marked through the antioxidant enzyme markers' determination in the study of hepatic tissues and DNA. The results obtained in our current study are in accordance with those reported in previous works related to the impact of $\mathrm{CCl}_{4}$ on the liver [39,46-51].

$\mathrm{CCl}_{4}$ is reported to produce free radicals, which affect the cellular permeability of hepatocytes, subsequently leading to elevated levels of serum biochemical parameters such as ALT, AST and ALP [51]. This marks a damaged structural and functional integrity of the liver cell membranes, since these cytosolic enzymes are only released into circulation after hepatic cellular damage. An increase in ALT enzyme activity is almost always due to hepatocellular damage and is usually accompanied by an increase in AST and ALP. Oral administration of both fresh and dried olive leaf extracts produced a significant decrease in serum ALT, AST and ALP levels in $\mathrm{CCl}_{4}$-induced rats, pointing to their hepatoprotective effect. The reduced concentrations of these markers as a result of olive leaf extract administration observed during the present study might be due to the presence of bioactive compounds such as phenolic and triterpenoid compounds; although, there is a difference observed between fresh and dried leaf extracts (Table 1). As in the present study, previous research works on olive leaf extracts showed that $\mathrm{CCl}_{4}$ caused significant elevation of ALT, AST, ALP activities, while pretreatment with 
olive leaf extracts significantly suppresses the increase in their levels [24,25]. It has been reported that effective hepatoprotective agents must suppress the increase in ALT activity and bring it closer to a normal level in order to induce liver-healing. This would suggest that agents that can lower ALP levels may be useful in hepatoprotection [9].

The fluidity of the biological membrane as well as some enzyme activities can be affected by lipid peroxidation [36]. In our research work, we observed how treatment with FLE and DLE extracts significantly reduced lipid peroxidation level in $\mathrm{CCl}_{4}$ treated rats, which suggests that the lipid-oxidation inhibition was exerted by the $\mathrm{SC}-\mathrm{CO}_{2}$ olive leaf extracts. The generated toxic radicals could be masked through the antioxidants present in the extracts. Amongst the reactive species marker of oxidative stress in cells, we find the highly reactive compound MDA [6]. An increase in MDA levels in tissue sections as a result of $\mathrm{CCl}_{4}$ treatment signifies that lipid oxidation has increased, which subsequently causes tissue injury and the intrinsic cell system failure to eliminate exogenous hepatotoxin agents. In our study, the treatment with $\mathrm{SC}-\mathrm{CO}_{2}$ olive leaf extracts showed a significant reduction in lipid peroxidation levels in $\mathrm{CCl}_{4}$-treated rats, demonstrating the capacity of the extracts to reduce such severe alterations. The same behavior was observed for the elevated level of protein carbonyl groups considered as an indicator of protein oxidation. Our results are in agreement with those reported in the literature. In fact, when investigating the protective activity of dried olive leaf extract on $\mathrm{CCl}_{4}$-induced liver damage in rats, the researchers reported that the concentration of MDA significantly increased in rats administered $\mathrm{CCl}_{4}$ when compared to the control group [25]. A similar observation for increasing MDA levels was reported in another study [24] after which a significant decrease was registered in pretreated rats with (methanolic or butanolic) olive leaf extracts in comparison to $\mathrm{CCl}_{4}$-treated rats. Moreover, ethanolic olive leaf extract produced a significant decrease in lipid peroxidation levels in the liver of rats with fluoxetine-induced hepatotoxicity [30].

GPx is an enzyme with peroxidase activity which assures the protection from oxidative damage [9]. GPx catalyzes the reduction in $\mathrm{H}_{2} \mathrm{O}_{2}$ or organic peroxide to water or alcohol [52]. Other important antioxidant enzymes are SOD and CAT. SOD is a key enzyme with the ability to convert superoxide radicals into hydrogen peroxide and molecular oxygen, while CAT enhances the conversion of $\mathrm{H}_{2} \mathrm{O}_{2}$ to water and molecular oxygen.

In this study, high activities of GPx, SOD and CAT were observed following $\mathrm{CCl}_{4}$ intoxication. Similar observation for SOD was reported in another research on the hepatoprotective effect of extracts of Cnestis ferruginea against $\mathrm{CCl}_{4}$-induced toxicity [46]. High antioxidant enzyme activities of tissues and organs do not mean efficient protective potential against oxidative stress caused by $\mathrm{CCl}_{4}$ intoxication. It was found that antioxidant enzyme mRNA expression and enzyme activity were induced by the exposure of hepatocytes to hydrogen peroxide for $24 \mathrm{~h}$ [53]. Thus, the increase in CAT, SOD, and GPx activities observed in the liver are probably partly due to the elevated hydrogen peroxide content generated during the metabolism of $\mathrm{CCl}_{4}$ in the body, which lead to up-regulation of gene expression of antioxidant enzyme mRNA and consequently induced an increase in their activities in the liver tissue [54]. The elevated catalase and GPX activities in liver tissue may indicate a large increase in hydrogen peroxide; however, we cannot state to what degree the process of hydrogen peroxide removal is effective [55].

Additionally, the pretreatment of $\mathrm{CCl}_{4}$-intoxicated rats with FLE or DLE showed a marked decrease in the activities of antioxidant enzymes compared to the $\mathrm{CCl}_{4}$-only group. The protective effect of the extracts in $\mathrm{CCl}_{4}$-treated rats is manifested by their capacity to maintain the redox balance marked by the levels of antioxidant enzymes that changed to a figure close to that registered for the control group [9].

Histopathological studies also support the biochemical analysis. The liver histology was improved after co-treatment with SC-CO $\mathrm{CO}_{2}$ extracts in comparison to the $\mathrm{CCl}_{4}$ only-treated group, suggesting the hepatoprotective capacity of tested extracts against tissue fibrosis. Olive leaves exerted a significant protective effect against $\mathrm{CCl}_{4}$-induced liver damage as marked by the improvement of serum oxidative stress biomarkers and the histology of tissue sections. 
The results also showed that $\mathrm{CCl}_{4}$ administration could induce hepatic fibrosis detected by Sirius Red and Masson's Trichrome staining, as manifested by excessive collagen deposition in the hepatic tissue. These findings were in line with other studies showing that $\mathrm{CCl}_{4}$ is able to induce liver fibrosis [56]. The fibrosis status could be related to the activation of hepatic stellate cells (HSCs) as a result of elevated levels of a variety of inflammatory cytokines induced by $\mathrm{CCl}_{4}$ intoxication, as reported in previous studies [57].

Administering FLE or DLE along with $\mathrm{CCl}_{4}$ significantly reduced liver fibrosis. These data support the efficacy of FLE or DLE in reducing the hepatocellular toxic effects of $\mathrm{CCl}_{4}$ and in suppressing the activation and proliferation of HSCs. This positive effect could be due to inflammation reduction. These findings are in line with recent studies that indicate that herbal bioactive molecules are effective against fibrosis in hepatic tissues [58,59].

Despite that significant effect observed for both DLE and FLE extracts, the different composition of tested extracts highlights the importance of phenolic compounds from different classes and triterpenoids as bioactive compounds. Concerning chemical differences related to phenolic compounds, it has to be taken into account that the DLE extract was characterized by the presence of high quantities of hydroxytyrosol and oleuropein isomer. Evaluating the hepatoprotective effect of oleuropein purified from olive leaves, it was found that its administration during ethanol-induced toxicity in rats improves the antioxidant defense system and reduces the levels of lipid peroxides [5]. In another study, oleuropein- and hydroxytyrosol-rich olive leaf extracts revealed hepatoprotective effects against high-fat diet-induced metabolic disorders in rats [14]. With regard to triterpenoids, maslinic acid was only detected and quantified in the FLE extract. Nevertheless, the hepatoprotective effects of triterpenoids present in SC-CO2 olive leaf extracts have not been reported previously.

Since active phenolics and triterpenoids may have not only additive but also synergic effects on hepatoprotection, future investigations are warranted to develop purified triterpenoid extracts and determine correlations between the olive leaf isolated compounds and the hepatoprotective activity parameters.

\section{Conclusions}

The findings of the present study revealed the capacity of olive leaf extracts obtained by supercritical $\mathrm{CO}_{2}$ extraction in repairing injuries caused by $\mathrm{CCl}_{4}$-induced hepatotoxicity in a rat model. The obtained results show that fresh and dried olive leaf extracts are able to ameliorate the perturbed biochemical parameters caused by $\mathrm{CCl}_{4}$ treatment. Moreover, $\mathrm{SC}-\mathrm{CO}_{2}$ olive leaf extract administration resulted in a reduction in elevated levels of liver lipid peroxidation, and a reduction in protein carbonyls due to $\mathrm{CCl}_{4}$ administration was observed. Serum biochemical markers affirmed the capacity of SC-CO extracts to protect DNA, and histopathological studies confirmed the capacity of olive leaf extracts to improve liver fibrosis caused by $\mathrm{CCl}_{4}$ treatment. Therefore, olive leaf contributes to health benefits and it is a potential source of powerful antioxidant compounds. In conclusion, the current research indicates that $\mathrm{SC}-\mathrm{CO}_{2}$ extracts from olive leaves have an in vivo protective effect against $\mathrm{CCl}_{4}$-induced injury in rats' livers. Such a biological study is extremely important to highlight the usefulness of olive tree leaves among plants stated as having hepatoprotective activities. Olive leaves, precious by-products from which we have recovered bioactive compounds by green extraction technology, can be reused for agronomic, food, nutraceutical, and pharmaceutical applications.

Author Contributions: Conceptualization, A.T., A.F. and J.L.-S.; methodology, A.F. and A.T.; software, A.F., A.E.M.; A.T.; validation, D.A.-R., M.S.A. and L.G.; investigation, A.T.; A.F., A.E.M.; data curation, A.T.; A.F.; writing-original draft preparation, A.T.; writing-review and editing, A.F. and J.L.-S.; visualization, D.A.-R.; supervision, R.M. and D.A.-R.; project administration, R.M., A.S.-C. and J.L-S. All authors have read and agreed to the published version of the manuscript.

Funding: This study was supported by the Tunisian Ministry of Higher Education and Scientific Research (LR15CBBC05), the Spanish Ministry of Economy and Competitiveness (MINECO) (project AGL2015-67995-C3-2) and Junta de Andalucia, Andalucian Government, Spain (B-AGR-466-UGR18). 
Acknowledgments: The authors would like to thank Rached Raddadi, Hafedh Trabelsi, and Jihen Jeffel, technicians at Anatomopathology Laboory, Gafsa, Tunisia, for their assistance in histological studies.

Conflicts of Interest: The authors declare no conflict of interest.

\section{References}

1. Karthikeyan, J. Enzymatic and non-enzymatic antioxidants in selected Piper species. Indian J. Exp. Biol. 2003, 41, 135-140.

2. Pereira Rodrigues, O. Characterization of Phenolic Constituents of Medicinal Plants and Evaluation of Pharmacological Activities: Focus in Antioxidant and Anti-Inflammatory Properties; University of Salamanca-Faculty of Pharmacy: Salamanca, Spain, 2013.

3. Krishna, M.G.; Pallavi, E.; Ravi, K.B.; Ramesh, M.; Venkatesh, S. Hepatoprotective activity of Ficus carica Linn. leaf extract against carbon tetrachloride-induced hepatotoxicity in rats. Daru 2007, 15, 162-166.

4. Nandakishor, S.D. Effect of Microbially Synthesized Eicosapentaenoic Acid on Carbon Tetrachloride Induced Hepatotoxicity. J. Dev. Drugs 2014, 4, 2-5. [CrossRef]

5. Alirezaei, M.; Dezfoulian, O.; Kheradmand, A.; Neamati, S.; Khonsari, A.; Pirzadeh, A. Hepatoprotective effects of purified oleuropein from olive leaf extract against ethanol-induced damages in the rat. Iran. J. Vet. Res. 2012, 13, 218-226.

6. Brent, J.A.; Rumack, B.H. Role of free radicals in toxic hepatic injury I. Free radical biochemistry. Clin. Toxicol. 1993, 31, 139-171. [CrossRef]

7. Mccord, J.M. Human disease, free radicals, and the oxidant/antioxidant balance. Clin. Biochem. 1993, 26, 351-357. [CrossRef]

8. Koruk, M.; Taysi, S.; Savas, M.C.; Yilmaz, O.; Akcay, F.; Karakok, M. Oxidative stress and enzymatic antioxidant status in patients with nonalcoholic steatohepatitis. Ann. Clin. Lab. Sci. 2004, 34, 57-62.

9. Alqasoumi, S.I.; Abdel-Kader, M.S. Screening of some traditionally used plants for their hepatoprotective effect. In Phytochemicals as Nutraceuticals-Global Approaches to Their Role in Nutrition and Health; Venketeshwer, R., Ed.; InTechOpen: London, UK, 2012; pp. 255-278. ISBN 978-953-51-0203-8.

10. Bagali, R.S.; Jalalpure, S.S.; Patil, S.S. In-vitro Antioxidant and In-Vivo Hepatoprotective Activity of Ethenolic Extract of Tectona grandis Bark Against CCl4 Induced Liver Injury in Rats. Pharmacogn J. 2020, 12, 598-602. [CrossRef]

11. Kingsley, U.I. Ameliorative effect of hydroalcoholic extracts of Nigella sativa seed against CCl4-induced acute liver injury in rats. J. Drug Deliv. Ther. 2020, 10, 164-169.

12. Vani, M.; Rahaman, S.A.; Rani, A.P. Hepatoprotective studies of floral extracts of Gomphrena serrata L. and piperic acid on CCl 4 induced hepatotoxicity. Indian J. Nat. Prod. Resour. 2019, 10, 238-251.

13. Rashmi, K.; Shenoy, K.B. Hepatoprotective studies of aqueous leaf and root extracts of Barringtonia acutangula (L.) Gaertn. against ethanol induced hepatic stress in rats. Indian J. Tradit. Knowl. 2020, 19, 152-157.

14. Fki, I.; Sayadi, S.; Mahmoudi, A.; Daoued, I.; Marrekchi, R.; Ghorbel, H. Comparative Study on Beneficial Effects of Hydroxytyrosol- and Oleuropein-Rich Olive Leaf Extracts on High-Fat Diet-Induced Lipid Metabolism Disturbance and Liver Injury in Rats. Biomed Res. Int. 2020, 2020, 1-15. [CrossRef] [PubMed]

15. Feriani, A.; Tir, M.; María, A.; Caravaca, G.; Contreras, M.; Taamalli, A.; Segura-Carretero, A.; Ghazouani, L.; Mufti, A.; Tlili, N.; et al. Zygophyllum album leaves extract prevented hepatic fibrosis in rats, by reducing liver injury and suppressing oxidative stress, inflammation, apoptosis and the TGF- $\beta 1 /$ Smads signaling pathways. Exploring of bioactive compounds using HPLC-DAD-ES. Inflammopharmacology 2020. [CrossRef] [PubMed]

16. Pereira, O.; Macias, R.; JPerez, M.; JGMarin, J.; Cardoso, S. Protective effects of phenolic constituents from Cytisus multiflorus, Lamium album L. and Thymus citriodorus on liver cells. J. Funct. Foods 2013, 5, 1170-1179. [CrossRef]

17. Herrero, M.; Temirzoda, T.N.; Segura-Carretero, A.; Quirantes, R.; Plaza, M.; Ibañez, E. New possibilities for the valorization of olive oil by-products. J. Chromatogr. A 2011, 1218, 7511-7520. [CrossRef] 
18. El-seedi, H.R.; Khalifa, S.A.M.; Yosri, N.; Khatib, A.; Chen, L.; Saeed, A.; Efferth, T.; Verpoorte, R. Plants mentioned in the Islamic Scriptures (Holy Qur' ân and Ahadith ): Traditional uses and medicinal importance in contemporary times. J. Ethnopharmacol. 2019, 243, 112007. [CrossRef]

19. Schwingshackl, L.; Krause, M.; Schmucker, C.; Hoffmann, G.; Rücker, G.; Meerpohl, J.J. Impact of different types of olive oil on cardiovascular risk factors: A systematic review and network meta-analysis. Nutr. Metab. Cardiovasc. Dis. 2019, 29, 1030-1039. [CrossRef]

20. Castejón, M.L.; Montoya, T.; Alarcón-de-la-Lastra, C.; Sánchez-Hidalgo, M. Potential Protective Role Exerted by Secoiridoids from Olea europaea L. in Cancer, Cardiovascular, Neurodegenerative, Aging-Related, and Immunoinflammatory Diseases. Antioxidants 2020, 9, 149. [CrossRef]

21. Romani, A.; Ieri, F.; Urciuoli, S.; Noce, A.; Marrone, G.; Nediani, C.; Bernini, R. Health Effects of Phenolic Compounds Found in Extra-Virgin Olive Oil, By-Products, and Leaf of Olea europaea L. Nutrients 2019, 11, 1776. [CrossRef]

22. Talhaoui, N.; Trabelsi, N.; Taamalli, A.; Verardo, V.; Gómez-Caravaca, A.M.; Fernández-Gutiérrez, A.; Arraez-Roman, D. Olea europaea as Potential Source of Bioactive Compounds for Diseases Prevention. In Studies in Natural Products Chemistry; Atta-ur-Rahman, Ed.; Elsevier: Amsterdam, The Netherlands, 2018; Volume 57, pp. 389-411. ISBN 9780444640574.

23. Taamalli, A.; Arráez Román, D.; Gómez Caravaca, A.M.; Zarrouk, M.; Segura Carretero, A. Geographical Characterization of Tunisian Olive Tree Leaves (cv. Chemlali) Using HPLC-ESI-TOF and IT/MS Fingerprinting with Hierarchical Cluster Analysis. J. Anal. Methods Chem. 2018, 2018, 1-10. [CrossRef]

24. Soliman, S.S.; Soliman, M.A.E. Protective Activities of Some Extracts from Olea europaea Leaves towards $\mathrm{CCl} 4$-Induced Hepatotoxicity in Rats. Chem. Res. J. 2019, 4, 62-75.

25. Vidičević, S.; Jelena, T.; Stanojević, Ž.; Isaković, A.; Mitić, D.; Ristić, D.; Dekanski, D. Standardized Olea europaea L. leaf extract exhibits protective activity in carbon tetrachloride-induced acute liver injury in rats: The insight into potential mechanisms. Arch. Physiol. Biochem. 2019, 1-9. [CrossRef]

26. Jemai, H.; Mahmoudi, A.; Feryeni, A.; Fki, I.; Bouallagui, Z.; Choura, S.; Chamkha, M.; Sayadi, S. Hepatoprotective Effect of Oleuropein-Rich Extract from Olive Leaves against Cadmium-Induced Toxicity in Mice. Biomed Res. Int. 2020, 2020, 1-9. [CrossRef] [PubMed]

27. Al-basher, G.I. Anti -fibrogentic and hepatoprotective potential of methanolic olive extract on cadmium induced toxicity in rats. Life Sci. J. 2018, 15, 1-11. [CrossRef]

28. Taha, M.E.S.; Kamal, A.M.; Ibrahim, D.R. Possible protective effect of olive leaves extract on paracetamol induced hepatotoxicity in male albino rats. Biosci. J. 2020, 36, 245-255. [CrossRef]

29. Al-Attar, A.M.; Alrobai, A.A.; Almalki, D.A. Effect of Olea oleaster and Juniperus procera leaves extracts on thioacetamide induced hepatic cirrhosis in male albino mice. Saudi J. Biol. Sci. 2016, 23, 363-371. [CrossRef]

30. Elgebaly, H.A.; Mosa, N.M.; Allach, M.; El-massry, K.F.; El-Ghorab, A.H.; Al Hroob, A.M.; Mahmoud, A.M. Olive oil and leaf extract prevent fluoxetine-induced hepatotoxicity by attenuating oxidative stress, inflammation and apoptosis. Biomed. Pharmacother. 2018, 98, 446-453. [CrossRef]

31. Maalej, A.; Mahmoudi, A.; Bouallagui, Z.; Fki, I.; Marrekchi, R.; Sayadi, S. Olive phenolic compounds attenuate deltamethrin-induced liver and kidney toxicity through regulating oxidative stress, inflammation and apoptosis. Food Chem. Toxicol. 2017, 106, 455-465. [CrossRef]

32. Nastic, N.; Borras-Linares, I.; Lozano-Sánchez, J.; Švarc-Gaji' J.; Segura-carretero, A. Comparative assessment of phytochemical profiles of comfrey (Symphytum officinale L.) root extracts Obtained by Different Extraction Techniques. Molecules 2020, 25, 837. [CrossRef]

33. Sánchez-Camargo, A.D.; Parada-Alonso, F.; Ibáñez, E.; Cifuentes, A. Recent applications of on-line supercritical fluid extraction coupled to advanced analytical techniques for compounds extraction and identification. J. Sep. Sci. 2018, 1-42. [CrossRef]

34. Armenta, S.; Garrigues, S.; Esteve-turrillas, F.A.; De la Guardia, M. Green extraction techniques in green analytical chemistry. Trends Anal. Chem. 2019, 116, 248-253. [CrossRef]

35. Temelli, F.; Guculu-Ustundag, O. Supercritical technologies for further processing of edible oils. In Bailey's Industrial Oil and Fat Products; Shahidi, F., Ed.; John Wiley \& Sons, Inc.: Hoboken, NJ, USA, 2005; pp. $397-432$.

36. Carrasco-Pancorbo, A.; Cerretani, L.; Bendini, A.; Segura-Carretero, A.; Gallina-Toschi, T.; Fernández-Gutiérrez, A. Analytical determination of polyphenols in olive oils. J. Sep. Sci. 2005, 28, 837-858. [CrossRef] [PubMed] 
37. Taamalli, A.; Arráez-Román, D.; Barrajón-Catalán, E.; Ruiz-Torres, V.; Pérez-Sánchez, A.; Herrero, M.; Ibañez, E.; Micol, V.; Zarrouk, M.; Segura-Carretero, A.; et al. Use of advanced techniques for the extraction of phenolic compounds from Tunisian olive leaves: Phenolic composition and cytotoxicity against human breast cancer cells. Food Chem. Toxicol. 2012, 50, 1817-1825. [CrossRef]

38. Taamalli, A.; Lozano, J.; Jebabli, H.; Trabelsi, N.; Abaza, L.; Segura-Carretero, A.; Cho, J.Y.; Arraez-Roman, D. Monitoring the bioactive compounds status in Olea europaea according to collecting period and drying conditions. Energies 2019, 12, 947. [CrossRef]

39. Tipoe, G.L.; Leung, T.M.; Liong, E.C.; Lau, T.Y.H.; Fung, M.L.; Nanji, A.A. Epigallocatechin-3-gallate (EGCG) reduces liver inflammation, oxidative stress and fibrosis in carbon tetrachloride (CCl4)-induced liver injury in mice. Toxicology 2010, 273, 45-52. [CrossRef] [PubMed]

40. Levine, R.L.; Garland, D.; Oliver, C.N.; Amici, A.; Climent, I.; Lenz, A.G.; Ahn, B.W.; Shaltiel, S.; Stadtman, E.R. Determination of carbonyl content in oxidatively modified proteins. In Methods in Enzymology; Elsevier: Hoboken, NJ, USA, 1990; pp. 464-478.

41. Marklund, S.; Marklund, G. Involvement of the superoxide anion radical in the autoxidation of pyrogallol and a convenient assay for superoxide dismutase. Eur. J. Biochem. 1974, 47, 469-474. [CrossRef]

42. Aebi, H. Catalase in vitro. In Methods in Enzymology; Packer, L., Ed.; Elsevier: New York, NY, USA, 1984; pp. 121-126.

43. Flohé, L.; Günzler, W. Assays of glutathione peroxidase. In Methods in Enzymology; Packer, L., Ed.; Elsevier: New York, NY, USA, 1984; pp. 114-121.

44. Kanno, S.-I.; Shouji, A.; Hirata, R.; Asou, K.; Ishikawa, M. Effects of naringin on cytosine arabinoside (Ara-C)-induced cytotoxicity and apoptosis in P388 cells. Life Sci. 2004, 75, 353-365. [CrossRef] [PubMed]

45. Al-Attar, A.M.; Shawush, N.A. Influence of olive and rosemary leaves extracts on chemically induced liver cirrhosis in male rats. Saudi J. Biol. Sci. 2015, 22, 157-163. [CrossRef]

46. Rahmat, A.; Dar, F.; Choudhary, I. Protection of $\mathrm{CCl} 4$-induced liver and kidney damage by phenolic compounds in leaf extracts of Cnestis ferruginea (de Candolle). Pharmacognosy Res. 2014, 6, 19-28. [CrossRef]

47. Szende, B.; Timár, F.; Hargitai, B. Olive oil decreases liver damage in rats caused by carbon tetrachloride (CCl4). Exp. Toxicol. Pathol. 1994, 46, 355-359. [CrossRef]

48. Dineshkumar, G.; Rajakumar, R.; Mani, P.; Johnbastin, T.M.M. Hepatoprotective activity of leaves extract of eichhornia crassipes against CCl4 induced hepatotoxicity albino rats. Int. J. Pure Appl. Zool. 2013, 1, $209-212$.

49. Tlili, N.; Feriani, A.; Allagui, M.S.; Saadoui, E.; Khaldi, A.; Nasri, N. Effects of Rhus tripartitum fruit extract on CCl4-induced hepatotoxicity and cisplatin-induced nephrotoxicity in rats. Can. J. Physiol. Pharmacol. 2015, 94, 1-28. [CrossRef] [PubMed]

50. Essawy, A.E.; Abdel-Moneim, A.M.; Khayyat, L.I.; Elzergy, A.A. Nigella sativa seeds protect against hepatotoxicity and dyslipidemia induced by carbon tetrachloride in mice. J. Appl. Pharm. Sci. 2012, 2, 021-025. [CrossRef]

51. Kumar, P.V.; Sivaraj, A.; Elumalai, E.K.; Kumar, B.S. Carbon tetrachloride-induced hepatotoxicity in rats-Protective role of aqueous leaf extracts of Coccinia grandis. Int. J. Pharm. Tech. Res. 2009, 1, 1612-1615.

52. Castro, L.; Freeman, B.A. Reactive oxygen species in human health and disease. Nutrition 2001, 17, $163-165$. [CrossRef]

53. Rohrdanz, E.; Kahl, R. Alterations of antioxidant enzyme expression in response to hydrogen peroxide. Free Radic. Biol. Med. 1998, 24, 27-38. [CrossRef]

54. Shull, S.; Heintz, N.H.; Periasamy, M.; Manohar, M.; Janssen, Y.M.; Marsh, J.P.; Mossman, B.T. Differential regulation of antioxidant enzymes in response to oxidants. J. Biol. Chem. 1991, 266, 24398-24403.

55. Szymonik-Lesiuk, S.; Czechowska, G.; Stryjecka-Zimmer, M.; Słomka, M.; MĄldro, A.; Celiński, K.; Wielosz, M. superoxide dismutase, and glutathione peroxidase activities in various rat tissues after carbon tetrachloride intoxication. J. Hepatobiliary Pancreat Surg. 2003, 309-315. [CrossRef]

56. Catherine, T.; Piquet-pellorce, L.M.G.C.; Samson, M. Chlordecone potentiates hepatic fibrosis in chronic liver injury induced by carbon tetrachloride in mice. Toxicol. Lett. 2016. [CrossRef]

57. Li, D.; Friedman, S.L. Liver fibrogenesis and the role of hepatic stellate cells: New insights and prospects for therapy. J. Gastroenterol. Hepatol. 1999, 14, 618-633. [CrossRef] 
58. Mejri, H.; Tir, M.; Feriani, A.; Ghazouani, L.; Allagui, M.S.; Saidani-Tounsi, M. Does Eryngium maritimum seeds extract protect against $\mathrm{CCl} 4$ and cisplatin induced toxicity in rats: Preliminary phytochemical screening and assessment of its in vitro and in vivo antioxidant activity and antifibrotic effect. J. Funct. Foods 2017, 37, 363-372. [CrossRef]

59. Ogaly, H.A.; Eltablawy, N.A.; Abd-elsalam, R.M. Antifibrogenic influence of Mentha piperita L. essential Oil against CCl 4 -induced liver fibrosis in rats. Oxid. Med. Cell. Longev. 2018, 2018, 1-15. [CrossRef] [PubMed]

(c) (1) (C) 2020 by the authors. Licensee MDPI, Basel, Switzerland. This article is an open access article distributed under the terms and conditions of the Creative Commons Attribution (CC BY) license (http://creativecommons.org/licenses/by/4.0/). 